\title{
Northern Lights Instead of Workers' Rights: Volunteer Working Tourists in Finnish Lapland'
}

I Dr. Christopher Brennan ${ }^{2}$

Independent Researcher, University of Groningen, The Netherlands

\begin{abstract}
Research on volunteers in the tourism field often deals with the motivations of such persons as well as their effects on host locales, while research on the work conditions of tourism workers often focuses solely on paid employees. However, such research has not focused on the workplace conditions for volunteer working tourists in the tourism arena whose motivation, among other reasons, for seeking unpaid work opportunities is a dual role of tourism consumer. As volunteers are not formally employed, they are not entitled to legal workplace standards. This article examines, through netnographic research methods and thematic analysis, the workplace experiences of several volunteer working tourists in Finnish Lapland, considering how similar to precarious employment their situation is, to some extent enabled by their tourism mindset. This raises curious questions about the use of such labor, suggesting their future inclusion within discussions of precarious work.
\end{abstract}

\section{KEYWORDS}

Lapland / precarious work / volunteer tourism / working tourists

\section{Introduction}

apland in northern Finland is a key tourism destination, promoted as a magical land of Santa's reindeer, snow and ice, and northern lights, that draws just under one million tourists each year (YLE 2016). The region is home to many ski resorts, safari companies, hotels, and other tourism-related services that seek flexible, seasonal workers and, in addition to locals, many enterprises often employ foreigners from abroad. Lapland tourism workers are not an understudied population, as research has been done on the effects of tourism planning on local populations (Hakkarainen and Tuulentie 2008), gender in work in tourism (Veijola 2009), customer service in small businesses (Raudaskoski 2010), guides producing the forest as an environment that suits the tourism industry (Rantala 2010), the complex safety in wilderness guiding (Rantala \& Valkonen 2011), and safari guide recruitment in commercial nature tourism (Valkonen et al. 2013). While these studies review different aspects of tourism work and complex interactions with tourism consumers or demands of working in the volatile, sometimes precarious, tourism industry, investigation has not been made into the role or situation of those who seemingly function as employees for some entities yet formally are not volunteer working tourists. Using netnographic research methods and thematic analysis, this article examines the workplace experiences of volunteer working tourists in Finnish Lapland, looking at how akin to precarious employment their situation is as facilitated

\footnotetext{
${ }^{1}$ You can find this text and its doi at https://tidsskrift.dk/njwls/index.

${ }^{2}$ Corresponding author: brennglobal@gmail com
} 
by their tourism mentality. Such an occurrence, while ostensibly legal, raises interesting questions about to use volunteer labor within the tourism industry in Lapland and the presence or absence of workplace standards and safety, leaving this unique demographic susceptible to vulnerable working conditions.

\section{Theoretical background}

\section{Tourism work and precarious work}

Tourism, together with the hospitality industry (Baum 2012; Dow et al. 2009; Mayhew \& Quinlan 2001; McKay et al. 2012; Sargeant \& Frazer 2009; Wilson 2004), is regularly identified amongst sectors vulnerable to precarious situations of work for employees. The industry is likewise specifically mentioned as susceptible to such in certain regions, for example, in part-time work in Austria (Hinterseer 2013) and precarious employment in Europe (McKay et al. 2012). In academic contexts, 'precarious' work refers to atypical or non-standard employment situations, also introduced by some as 'new' forms of work (Kravaritou-Manitakis 1988). This incorporates employment that is unsecure, where workers are entangled in vulnerable situations whether with regards to work conditions, salary, longevity, or treatment (see Campbell et al. 2009; Dow et al. 2009; Fudge \& Owens 2006; Mayhew \& Quinlan 2001; Standing 2010). As Kalleberg writes, precarious work denotes, '...employment that is uncertain, unpredictable, and risky from the point of view of the worker' $(2009, \mathrm{p} .2)$. Situations of precarious work, if generalizing, occur more often when there is a surplus of labor, where workers are pressed to accept work at any conditions, cost, or compromise of values (Kalleberg 2009, p. 2-3; McKay et al. 2009, p. 10). When defining if an employment situation is precarious in nature, there are typically four dimensions for consideration:

1. The degree of belief that work will continue;

2. Identifying who controls the labor process and the presence or absence of professional standards or trade union;

3. The degree of legal recognized standards and protection the work situation and environment involves;

4. Level of pay

(Dow et al. 2009, p. 3; Fudge \& Owens 2006, p.11).

The most often mentioned persons, some of whom are found working within the tourism industry, include migrant workers, young workers, minority ethnic workers, women workers, agency workers, older workers, immigrants, students, apprentices, and interns (Bhalla \& McCormick 2009; Kretsos 2010; Mayhew \& Quinlan 2001; Porthé et al. 2009; Standing 2010; Wilson 2004). Precarious work environments are not uncommon in studies about tourism workers specifically. Such situations have been found in research on tourism workers in Seychelles (Lee et al. 2014) and mentioned in research on tourism workers in Lapland (see Veijola 2009).

Logically, studies on tourism workers focus on legal, formal employees. However, this research has examined the occurrence of volunteers who work in for-profit tourism services in Lapland. Such persons fall into a 'gray' area within discussion of workplace 
rights and entitlements, and as they are not employed, formal standards of workplace regulations do not apply. These volunteers work in established companies without a formal work contract or agreement, potentially due their predominating role as a tourism consumer, or working tourist.

\section{Working tourists}

The phrase 'working tourist' was first devised by Uriely and Reichel as, '... tourists who engage in situations that combine work with tourism' (2000, p. 268). More precisely, Uriely created the four categories below to distinguish between motivations and characteristics of persons who combine travel and work (Fig. 1).

Figure I Types of 'traveling workers' and 'working tourists' (Uriely 200I).

\begin{tabular}{|c|c|c|c|c|}
\hline \multirow[b]{3}{*}{$\begin{array}{l}\text { Dimensions } \\
\text { of comparison }\end{array}$} & \multicolumn{4}{|c|}{ Types of travelers } \\
\hline & \multicolumn{2}{|c|}{ Working tourists } & \multicolumn{2}{|c|}{ Traveling workers } \\
\hline & $\begin{array}{l}\text { Working-holiday } \\
\text { tourists }\end{array}$ & $\begin{array}{l}\text { Non-institutionalized } \\
\text { working tourists }\end{array}$ & $\begin{array}{l}\text { Migrant tourism } \\
\text { workers }\end{array}$ & $\begin{array}{l}\text { Traveling } \\
\text { professional } \\
\text { workers }\end{array}$ \\
\hline $\begin{array}{l}\text { Work and touristic } \\
\text { motivations }\end{array}$ & $\begin{array}{l}\text { Work is grasped } \\
\text { as a recreational } \\
\text { activity that is } \\
\text { part of the tourist } \\
\text { experience }\end{array}$ & $\begin{array}{l}\text { Work in order to } \\
\text { finance a prolonged } \\
\text { travel. }\end{array}$ & $\begin{array}{l}\text { Travel in order to } \\
\text { 'make a living' and } \\
\text { 'have fun' at the } \\
\text { same time. }\end{array}$ & $\begin{array}{l}\text { Travel in order } \\
\text { to exercise } \\
\text { work. Engage in } \\
\text { tourist related } \\
\text { activities as a } \\
\text { by-product of } \\
\text { the excursion. }\end{array}$ \\
\hline Work characteristics & $\begin{array}{l}\text { Unskilled but usu- } \\
\text { ally recreational } \\
\text { manual labor. } \\
\text { Extraordinary work. } \\
\text { Unpaid work. }\end{array}$ & $\begin{array}{l}\text { Unskilled and usually } \\
\text { unpleasant manual } \\
\text { labor. Occasional } \\
\text { work. Low-paid and } \\
\text { non-prestigious } \\
\text { work. }\end{array}$ & $\begin{array}{l}\text { Skilled or semi- } \\
\text { skilled work in tour- } \\
\text { ism economy. } \\
\text { Repetitive seasonal } \\
\text { employment. Unse- } \\
\text { cured and low-paid } \\
\text { employment. }\end{array}$ & $\begin{array}{l}\text { Professional, } \\
\text { official } \\
\text { role, or business } \\
\text { related work. } \\
\text { Repetitive, } \\
\text { career } \\
\text { related work. } \\
\text { Prestigious and } \\
\text { well-paid work. }\end{array}$ \\
\hline $\begin{array}{l}\text { Demographic } \\
\text { profile }\end{array}$ & $\begin{array}{l}\text { Middle-class } \\
\text { young adults. }\end{array}$ & $\begin{array}{l}\text { Middle-class young } \\
\text { adults. }\end{array}$ & $\begin{array}{l}\text { Lower middle-class, } \\
\text { or working class sin- } \\
\text { gle and unattached } \\
\text { adults. Periodically } \\
\text { unemployed in their } \\
\text { home societies }\end{array}$ & $\begin{array}{l}\text { Middle, or } \\
\text { upper-middle } \\
\text { class adults }\end{array}$ \\
\hline
\end{tabular}

A difference between the two main categories is that for 'working tourists', travel or tourism is the main motivator within the pursuit of work, whereas for 'traveling workers', sustenance of a career or lifestyle is the principal motivation for employment mobility. Thus, working tourists would be keener to spend a single period with one employer that 
serves to meet the temporary tourist experience or short-term fiscal needs for continued travel. Studies on working tourists have discussed working holiday makers in Australia (Brennan 2014a, 2014b, 2014c; Harding \& Webster 2002; Jarvis \& Peel 2009, 2010; Kawashima 2010; Tan et al. 2009), in Canada (Duncan 2002), the global experiences of New Zealand working holiday makers (Wilson et al. 2010), and Taiwanese working holiday makers abroad (Ho et al. 2014). Uriely's category also includes 'unpaid' work, and so includes those also known as 'volunteer tourists'.

\section{Volunteer tourism}

Volunteer tourists are commonly seen as persons who travel to a particular destination to accept work without payment while simultaneously experiencing conventional elements of travel, and do so because of causes, personal beliefs, or interests (Wearing 2001). It is also often seen as a kind of tourism in which tourists pay to partake in humanitarian or conservation related projects (Mostafanezhad 2014).

Volunteer tourism as an occurrence is sought by individuals in direct contact with persons and/or hosts offering volunteer opportunities, or overseen by for-profit or non-profit entities that act as facilitators, connecting volunteers with hosts. A good amount of studies has been done on volunteer tourists/tourism, usually examining motivations of volunteers (Broad 2003; Brown \& Lehto 2005; McGehee \& Andereck 2008; Mustonen 2007). Volunteer tourists have also been divided into categories of volunteer-minded versus vacationminded practitioners (Brown \& Lehto 2005; Mustonen 2007; Wearing 2001). Studies also have examined the benefits of volunteer tourism for both tourist and host enclaves (Broad 2003; Brown \& Morrison 2003; Clifton \& Benson 2006; Ellis 2003; Gunderson 2005; McGehee \& Santos 2005; Uriely et al. 2003; Wearing 2001, 2002; Wearing et al. 2008), as well as negative impacts of the phenomena (Guttentag 2010). Research has also been done on volunteer tourists in northern Norway, near Lapland, about the creation of noncommodified volunteer experiences (Jæger \& Olsen 2016).

Predominantly, volunteer tourism research tends to be looked at from a tourismcentric theoretical perspective and discussed within tourism literature. It is not typical for labor research to investigate volunteer tourists despite their observed importance as a labor source for some localities and non-profits (Handy \& Brudney 2007, see also Jæger \& Olsen 2016); the world of work does not inspect those engaged in unpaid work for leisure or travel. If volunteers, as working tourists, engage in activities otherwise completed by formal employees, their occurrence is relevant to contemporary labor discussions, including precariousness.

In this article, a novel approach is taken in examining the offers of work for, and experiences of, volunteer working tourists in Finnish Lapland from the nexus of precarious work, working tourist, and volunteer tourist perspectives. The objective is to analyze how the experiences of these tourists demonstrates a situation similar to precarious employment as enabled by their touristic ambitions. This is of interest due to the observable recruitment of working tourists by for-profit Lapland service providers in various online mediums intended for volunteer tourists. Online testimonials of working tourists, found in personal blogs and news articles, offer insight into the actual experiences of volunteer working tourists with such providers, revealing the workplace environment. Testimonials about work tasks from a tourism mindset also offer candid and seemingly 
honest accounts as to the work experience; there is no muted response due to employer or researcher influence. While tourism work in Lapland, and in other areas, has been identified as precarious in prior research (see Veojola 2009), the use of volunteers instead of employees raises interesting questions about the practice, in particular the responsibility of liability in a workplace setting, as well as the potential circumvention of formal employment standards and regulations ${ }^{1}$.

\section{Method and Data}

The research used netnography in examining online mediums that discuss recruitment and experiences of volunteer working tourists in Finnish Lapland, as qualitative data is openly visible in work exchange websites where volunteers are recruited and in various online blogs and articles that volunteers produce. Similar data is also available from service provider websites and online job boards.

Netnography is a methodology similar to ethnography yet examines virtual, online communities and their characteristics. It is used in online market research, searching for qualitative examples of customer needs, selections, and opinions to be used for marketing feedback (Kozinets 2002, p.2). Field work sites can be varied in netnography since an online community or demographic can manifest in one or across multiple sites. Hence, the geographical location of research is a website, blog, forum, or message board, and the users or creators of these podiums form the group studied (Baym 2000; Correll 1995; Kozinets 2002; Kulavuz-Onal \& Vasquez 2013). Benefits of information obtained through netnography include the fact that data is often offered publicly and in a candid, open manner; sources do not have to be directly confronted by a researcher (Kay $\&$ Laberge 2002, p.29). It is a very unobtrusive approach, and due to the anonymity of the Internet, inspection can be done clandestinely. This can be conducive to sensitive research subjects (see Beckman \& Langer 2005) such as labor related studies, in some contexts, where actors may be less than transparent if enacting in questionable practices. With traditional research methods, the known presence of a researcher can affect and interfere with the normal practices of everyday life (Hammersley \& Atkinson 1995). Netnography has also been used in research on tourist experiences (see Rageh et al. 2013), demonstrating a similar approach as this research, minus the added precarious work perspective in analysis this research uses.

The data/media reviewed as part of this research was gathered from the following mediums:

1) Volunteer adverts listings on the work exchange website www.workaway.info;

2) The travel blog of an American couple, who quit their jobs to travel around the world and volunteered in Lapland;

3) The personal blog of a young British man who volunteered with a company in Lapland;

4) An online article in a major UK newspaper, describing the authors experience as a volunteer in Lapland;

5) Volunteer instruction PDFs from a Lapland service provider who actively recruits volunteer labor;

6) Several job adverts on www.mol.fi for tourism workers in Lapland ${ }^{2}$. 
Data was collected in PDF prints and screenshots made of the webpages reviewed, to preserve existence of data at that place and time, online. As web content can be edited, it is necessary to document such. The data provided on the multiple mediums accessed represented qualitative data from the community that includes both volunteer working tourists and the service provider hosts who they work for. As Kozinets writes that netnography is, '...based primarily on the observation of textual discourse' (2002, p.64), both categorical labels and testimonials within content were empirically examined. As there was no single medium where actors were conversing with each other, distinct examples were pulled from multiple mediums involved with volunteer working tourists in Lapland to give different, opposing perspectives and insight into phenomena not previously studied.

The data was analyzed using thematic analysis, which is used, '...to refer to patterns in the data that reveal something of interest regarding the research topic at hand' (King \& Horrocks 2010, p .149). From the data, themes were identified through the mediums employers used to recruit volunteers, the description of workplace conditions of the volunteer workers, and to what extent volunteers who function as employees are treated as, or granted the same workplace rights as, paid employees. What constitutes a 'theme' involves, '...the researcher making choices about what to include, what to discard, and how to interpret...' content (King \& Horrocks 2010, p.149). In the end, 'Themes are recurrent and distinctive features...characterizing particular perceptions and/or experiences, which the researcher sees as relevant...' (King \& Horrocks 2010, p.150). The criteria for these themes were based on the textual descriptions found that described the situation of the volunteer workplace by either the volunteer themselves, or the service provider using their labor. The descriptions within paid employment adverts were also reviewed to exemplify formal working conditions. The themes of discussion derived from the criteria and mediums are 1) recruiting volunteers who are also tourists, 2) extreme working conditions, and 3) liability and safety. These are discussed further below.

\section{Limitations}

It must be acknowledged that the testimonials found on blogs and in the online news article are from volunteers who worked at one particular husky farm in Lapland. The volunteer instruction PDF is from this same husky farm. While this could infer a case study, the practice of using volunteer tourist labor is not only done by this husky farm, nor only husky farms in general; the 10 listings from workaway.info were identified as being distinctly operating in the tourism sector in Lapland, with six of them being husky farms/tour operators and the other four being accommodation providers or resorts/ shops. Although these insights are from one service provider, the conditions of seasonal winter tourism work in Lapland carry common characteristics across jobs. Working sometimes long, flexible hours providing a service to international customers in extreme, cold conditions is not isolated to just husky work, albeit an outdoor position does incur longer periods in extreme weather than an indoor position. Likewise, in the host profiles on workaway.info, the reviews of volunteers who stayed and worked with the Lapland service providers can be seen. The overwhelming majority are positive in tone and reveal brief insight into the workplace environment and tasks performed. The difference with 
these reviews is that most are not as in-depth or content rich as personal blogs or news articles, which are positive in tone as well yet describe in much greater detail the work environment. The volunteer instruction PDF also provides greater insight into what parameters the service provider communicates to the incoming volunteer about issues, such as insurance. The host profiles on workaway.info and their subsequent reviews provide evidence to the wider extent of the use of volunteers among some service providers; however, a generalization to the extent of hardships encountered in the workplace is limited in the analysis to the one location that multiple online testimonials have been written about. Nevertheless, the content to be discussed below then gives birth to the question as to how prevalent are these conditions at other service providers, raising a need for further research about the phenomena.

Another limitation is the extent of validity of the data gathered in the used method. While netnography offers the chance to observe from a clandestine position, the data collected are textual accounts of behavior as opposed to first-hand observed behavior, such as that recorded when using ethnography. This creates potential for doubt regarding the accuracy of data discovered online. However, and as mentioned, netnography offers the chance to observe data offered publicly and in a candid, open manner; reflecting on the data gathered, the testimonials observed were not perceived to be given with malicious intent as they are, in contrast, praiseful of the experience gained from volunteering as working tourists despite being scrutinized here in the context of precarious work. Likewise, information published by service providers, including their adverts, is seen as legitimate representation of how they operate, as described by themselves. Overall and despite such limitation, the data collected is viewed as authentic in the assessment of the researcher and in the context of this research.

\section{Findings}

In empirical examination, the various mediums were all reviewed with relevance to how the experiences of volunteer working tourists in Lapland is akin to those of precarious workers, with different sites offering varying levels of insight into such. The sections that follow highlight the aspects of the phenomena, through various themes, that raise interesting discussion.

\section{Recruiting volunteers who are also tourists}

The descriptions of listings from tourism service providers in Finnish Lapland ${ }^{3}$ on the website www.workaway.info were observed as the website is, '...set up to promote fair exchange between budget travelers, language learners or culture seekers who can stay with families, individuals or organizations that are looking for help with a range of varied and interesting activities' (workaway.info 2016). All listings operating in the tourism industry categorically included Helping With Tourists as a work task volunteers participate in, confirming that volunteers were not only working within a tourism enterprise but also directly with tourists themselves. There are 10 host listings from Lapland; six are for husky farms/tour operators and four for accommodation providers or resorts/ shops. Almost all listings list duration of work barters as 5 hours per day, 5 days a week; 
however, several also state work hours vary depending on season or needs of dogs and/ or guests, demonstrating that in some occurrences, the work process depends on the needs of paying customers or the sled dogs who are a main attraction for safaris. All hosts offer accommodation and food in exchange for volunteer labor, as well as the extra benefits as to why volunteers should work with them specifically. Almost all refer to access to extreme nature and outdoor activities only possible in the far north, such as hiking, skiing, snowmobiling, or exploring national parks, while some specifically mention the ability to see the northern lights, a phenomenon that attracts thousands of tourists to Lapland each year. Accommodation providers in Australia have also been known to recruit working tourists as well, who sometimes work for an accommodation barter in unique, remote locations (Brennan 2014a). This echoes Uriely's (2001) notion of work motivation aligned to part of a tourist experience, and evidence of this allure is found in the blog of one Lapland volunteer. He writes:

'What made this even more spectacular was that the Northern Lights came out as we were driving along (on dog sleds) and gave one of their most majestic displays yet. My doubts the day before (about leaving) were completely blown away and I knew at the moment that that was the reason I'd come to the Arctic and it was everything I could have hoped for and more' (Lonan 2013).

The excerpt expresses uncertainty about his choice to volunteer yet he later clearly states that, 'In very few jobs would you face such long hours and cold temperatures, but also in very few jobs would you get to drive a 12 dog sled team through the Arctic wilderness with the Northern Lights overhead', revealing insight into to his motivation. A writer for the Telegraph also revealed that her motives for volunteering in Lapland were also tourism aligned:

'I tried to explain my decision to friends and colleagues, were unclear. But, at 26, I was restless. I was dreaming of Arctic landscapes, cold and bleak expanses...' (Telegraph 2013).

While the benefits of such work motivate volunteers, they also ostensibly motivate the employers to recruit these distinctly minded persons. A PDF guide of a husky safari company that recruits volunteers, and where the volunteers above worked, mentions that:

'Of late, we have also had numerous approaches to various volunteer-based websites (HelpX, Workaway, 7interchange, Woofers etc. ${ }^{4}$. However, we are probably not quite like some alternative options on these websites... We want people to be very aware about what they will be getting into, coming here and expect it to be like a job but with great perks'. ${ }^{5}$

The company actively operated on websites that are for travel and work barter exchange, and hint at the similar 'perks' of working in the region like the workaway.info listings, albeit more so identifying the volunteer position as like a 'job'. Nevertheless, a volunteer experience expected to be 'like a job' conversely is not a formal 'job', and hence workplace entitlements and standards do not exist, relating to the second dimension of precarious work (Fudge \& Owens 2006); it would be a 'job' without any rights. The use of tourism activities to recruit working tourists has been observed on a wide scale in 
Australia, however in that context, those performing work tasks did so within parameters of formal employment enabled by working holiday visas (Brennan 2014a, 2014b).

Volunteer mediums such as workaway.info are geared toward travelers looking for volunteer opportunities internationally, as they list hosts from over 155 different countries. International workers are quite common within the tourism industry, even in Lapland, and in some destinations specifically are recruited from abroad (see Lee et al. 2014). Although Guttentag argues volunteer tourists frequently perform jobs that locals could do instead (2010), many Lapland service providers operate in remote areas where nature is abundant, yet people are not. Hence, a reason for recruiting volunteers keen to experience the solitude and nature Lapland offers.

While such recruitment for volunteers on work exchange mediums by tourism service providers may seem a simple exchange of labor for food, accommodation, and a chance to satisfy unique adventure pursuits, the in-depth experiences of such volunteer working tourists can paint a more discerning picture.

\section{Extreme working conditions}

While the listings on workaway.info do include references left by previous volunteers as mentioned, these testimonials are often brief at best, simply reaffirming that volunteers enjoyed the experience of staying with services provider hosts and in the region. Searching further on the internet, it is possible to find blogs and articles of persons who have volunteered in Lapland, almost exclusively with a particular husky safari company ${ }^{6}$.

The work described reveals that volunteers, even if enjoying the tourism 'perks' of their job, are also pushed physically, working long hours in extreme winter conditions to meet the needs of the overwhelming number of tourists that come to Lapland each winter. As one volunteer writes:

'Lapland's economy depends almost entirely on a few short weeks before Christmas when visitors flood in from overseas. Suddenly it's all go as we try to run as many safaris as possible, often working from 7am till past midnight' (Telegraph 2013).

The extent to which the author was affected by working in such conditions was also revealed:

'To tell the truth, I'm running on empty. Every waking moment for weeks has been spent feeding or harnessing or sledding or shoveling snow or shoveling shit....on Christmas Eve, I'm sternly told off for not cleaning kennels properly, I'm so tired and it's so unfair that I find myself in tears...' (Telegraph 2013).

As Rantala et al. point out in their research on wilderness guiding in Finnish, Lapland, weather manipulates human practices by narrowing down or extending the possibilities for outdoor activities (2011). This external factor also dictates the flexibility needed to accommodate the services desired by tourists during the winter season, which business owners attempt to provide; if there is snow, there are safaris and tours to be had. With such unpredictability in working hours dependent on extreme weather, tourism 
employees seeking predictable compensation can be difficult to recruit, making willing volunteers looking for an extreme experience a more desirable replacement.

As volunteers work in barter for accommodation, their living space too is under the discretion of the hosts and personalities of other volunteers, who are not paid either. Describing her living conditions, one volunteer reveals:

'During this time of year there are about 10 volunteers living in the guide house... We live dorm style, with everyone in bunk beds in two rooms sharing a toilet and a shower. We rotate cooking and cleaning duties... and every night we have between 4-5 dogs from the farm who spend the night with us for either medical or socialization purposes' (Time that is given 2013).

Another volunteer likened the experience to communism:

'At times it felt like we were living in a little communist commune. Shared accommodation and meals, no wages but instead working for the "common good" and for the benefit of the team' (Lonan 2013).

While physical and emotional stress, and stressful living conditions, are aligned with fatigue of working so many hours and living in close quarters and days, so are the possibility of accidents:

'While freeing two dogs that have become tangled in the lines, I stupidly remove my gloves in -38C, and later find the color has drained away from the tips of my fingers. They also have an unpleasant needling sensation. "Congratulations" (the host) says..."Your first frostbite", (Telegraph 2013).

Frostbite is not an uncommon occurrence when working in temperatures that can get as low as $-40^{\circ} \mathrm{C}$, and was reported in the blogs of other volunteers as well ${ }^{7}$. Yet, even just as dangerous is the operating of a dog sled if not accustomed to doing so:

'So we set off from the farm (the dogs can take off at around $25 \mathrm{kms}$ an hour at the beginning) and the first corner I hit I came flying off, hitting my head on compacted snow. Nevertheless, I didn't let go of my team... and was instead pulled along behind for about 10 meters while my colleagues stopped my dogs and checked if I was alright' (Lonan 2013).

While not surprising that working outdoors in the Arctic with animals would be a demanding job, it is of curiousness to hear that these descriptions come from persons who undertake such extreme hardship as a volunteer seeking a unique experience. While their personal motivations or values may echo that of volunteers seeking authentic or unique experiences in the far north (see Jæger \& Olsen 2016), which are examined from the focus of tourism research, from a more precarious work aligned perspective, their experiences raise interesting questions about the practice of using volunteers in a commercial tourism enterprise seeing as how the employer controls not only the entire labor process but also the employees living arrangement (see Fudge \& Owens 2006). In 
the case of Jæger and Olsen's research (2016), volunteers are recruited to work at various festivals in northern Norway that last a few days. In the case of the Lapland service providers, volunteers are recruited to work for several months minimum, if not entire winter/tourism seasons.

\section{Liability and safety}

Adverts for tourism worker positions in Lapland ${ }^{8}$ from the website www.mol. $f^{9}$ were reviewed to give insight into normal conditions for legal tourism workers. Many of these adverts listed that work agreement was made according to the collective agreement for service workers in Finland. In formal tourism employment situations, this is typically a norm. The adverts included safari guide positions, taking tourists on different safaris on snowmobile, snowshoe, or foot, but not by dogsled. Interestingly, one advert that was from a husky safari company did not list any reference to the collective agreement, yet did mention exceptional amounts of hours, including a willingness to work weekends and holidays as needed, similar to the experiences of the volunteer testimonials found. 'Flexibility', or 'flex-work' or 'flex-time', is sometimes mentioned in discussions of precarious work situations (see Bird 2016), and although tourism industry employees in Finland would be required to have prior notification and agreement regarding their hours for work (PAM 2014, section 3), volunteers do not.

In fact, volunteers revealed that they were usually working 6 days a week:

'We have one day off a week, although you may work more than six days before you get a day off and it's never the same day' (Time that is given 2013).

Another volunteer blog confirmed the working 6 days a week ${ }^{10}$. While working exceptional hours as a seasonal tourism worker in Lapland is not unheard of, it again is interesting to point out that some of the persons doing so, in the context of this research, are volunteer working tourists. And while such volunteers may have a bartered agreement with their host for accommodation and food, it has been seen that during the winter tourist season, the hours of work requested are intense. However, there was no observed discussion of whether the barter changes from the hosts end. Does it? Or is the benefit of the additional work hours and prolonged, extreme conditions simply a unique experience of working in the Arctic, beyond that of which regional tourists would encounter. As one volunteer wrote, 'We also got the chance to go to a Sami reindeer gathering session, which is not something the tourists get to do!' (Lonan 2013). Such reflects the tourist mindset of these volunteers.

As these volunteer working tourists are working in a for-profit setting, interacting with customers in extreme conditions, the question can be raised as to what standards of safety are followed if national workplace standards do not apply to such persons, relating to the third dimension of precarious work (Fudge \& Owens 2006). This does not mean that certain safety guidelines would not be followed, as this would be paramount with regard to safety of paying customers. However, while customers may be covered by some insurances companies have, the volunteers are not necessarily. As a PDF guide for volunteers from a husky safari company reveals: 
'Whilst we have yet to have any volunteers to suffer anything more serious than frostbite which has been taken care of with indoor time and creaming it is not impossible to imagine bones being broken or muscles being torn during e.g., training season. Hence, please make sure that dog-sledding and snowmobiling is covered on your travel insurance if you will be here at a time of year when that is applicable'. ${ }^{11}$

The PDF continues on to state that volunteers without necessary personal insurances would not be allowed to perform work, so volunteers are indeed intended to have some protection in case of accident. Nevertheless, it is their 'travel' insurance that is to be their safety net should an accident occur in the workplace, the same type of insurance that tourists purchase when on holiday and undertaking tourist activities.

As six of the 10 listings in workaway.info were of husky farms recruiting volunteers to undertake tourism work in their operations, the question can be raised to how prevalent is the practice in Lapland and how would it affect the operation of such enterprises as well as the employment pool of other formal, tourism workers. One excerpt from a volunteer blog reveals the effect when volunteers leave suddenly or when the workers of another husky safari operator depart without notice:

'... we got through December and looked forward to a quiet January where we could relax a little and have some free time to perhaps ski and explore the area a little. But this elusive "lull" never arrived...This could be attributed to two factors. First of all we very suddenly lost three members of staff. One gave a week's notice that she was leaving while two others left on a day off with no warning to the rest of us whatsoever. They had their own reasons for leaving, and I don't bear any grudges, but they left us in a really shitty situation. We were now three people down (two of which were quite experienced while the other was incredibly helpful and useful) and it showed massively. We ran safaris where we felt stretched incredibly thin...I don't know if they thought about the effects on the rest of us but their sudden departure was felt heavily by those of us left behind. Even if they didn't consider that, one of them was dog medical Overseer... and essentially neglected her responsibility to the health and well-being of the dogs out there.... The second factor was that a (tour) company...had a contract with another dog-sledding farm which shut down, ironically due to all its staff walking out suddenly, and so we received all their safaris for the month of January, on top of all of our own' (Lonan 2013).

In such a scenario, if the working hours or work load of employees was increased significantly due to external factors, such employees would still be entitled to entitlements for fluctuations in work and pay, as outlined in contractual agreements. Volunteers have no contract. It is interesting to hear that persons would quit so suddenly yet perhaps not surprising if they were volunteers who did not experience the tourists benefits that attracted them to Lapland, or at least any more. Nevertheless, the departure of workers, formal or informal, at another service provider directly affected the workload of this volunteer working tourist ${ }^{12}$.

Another concern that arises in the use of volunteer working tourists as staff members are issues of safety related to experience in job task. While any job can have moments of routine, tourism work in the extreme cold includes unpredictable variables in the form of interaction with other humans, animals, and of course the weather. One would expect companies to have competent staff to provide the unique tourist experiences that paying 
customers travel so far for. Yet, if staff are new volunteers attracted each year as a constant labor source, then there is an ever-changing number of persons volunteering at any time. Who really knows what they are doing? As Rantala and Valkonen (2011) have found, safety in wilderness guiding in Lapland is a complex task. One volunteer described how their training initially came from other volunteers with limited experience themselves:

'In the very beginning we were trained by a 17 -year-old American girl who had been here for three months and would be returning to the US soon to start college' (Time that is given 2013).

Likewise, even if experienced, it can be questioned what responsibility do they have to paying customers who have purchased a service if not an employee of that service provider. As another volunteer described, he was leading safaris on his own:

'I got to take him (friend) out on the back of the snowmobile leading my first $20 \mathrm{~km}$ safari on my own which was pretty sweet and I was grateful to have his help' (Lonan 2013).

A volunteer functioning as a guide responsible for leading tourists on a safari without the assistance or accompaniment of formal, employed staff members raises questions pertinent not only to the safety of volunteers and tourist customers, but also such practices and if it potentially circumvents formal standards of employment leaving those who perform the work at-risk.

\section{Conclusion}

It is observed that multiple service providers in Finnish Lapland actively recruit international working tourists to serve in the functional operation of their businesses, using the allure of unique experiences in extreme natural conditions or working with distinctive animals as barter for their volunteer labor. While volunteer working tourists who participate in such work exchange may be satisfied with the unique experience that working in the tourism industry in the region may offer, the in-depth testimonies of volunteers at one husky farm gives glimpse into a work environment and tasks that, if otherwise completed by contracted employees, would be liable to workplace regulation. Their work situation is characterized by several dimensions of precarious employment, as described by Fudge and Owens (2006), and thus also can be seen as at-risk or precarious. Such a practice not only effects the environment in which a working tourist volunteer is surrounded, but can also have ramifications that extend beyond them. If a tourist experience can be used as an incentive to recruit labor to Lapland in place of offer of paid wages, then what effect would the expansion of such practice have on the job security of formal tourism workers? This is another form of precarity for tourism workers; they can be easily replaced by a surplus of willing, international volunteers. As one volunteer states, the experience is not a long-term commitment, but it is the temporary experience that is full-filled that potentially enables operators to recruit new volunteers each year:

'Some of you might think this is all bonkers and you would probably be right. Bear in mind that I'm a volunteer here and simply get my food and accommodation covered. In 
that respect, many of you might wonder what is driving me to be here. Why do I get up at 4:30am and persevere through minus 40 when I'm not getting paid for it? The truth is, I don't entirely know but I do know that I've never had a job quite like this and I don't think I ever will again. Initially it was the sense of adventure that attracted me...'(Lonan 2013).

Likewise, if employers need not legally abide by formal workplace standards of safety for those who perform work for them but are not employees, are they necessarily providing workplace entitlements and rights to formal employees that they are legally obliged to offer? Assuming there are legal employees at these enterprises, how should it be seen if there are two sets of persons performing similar tasks, one an employee the other a volunteer working tourist, and one is paid a salary and has workplace entitlements while the other is simply paid in 'adventure'? Hence, volunteer working tourists who function as employees in a for-profit setting should be considered as precarious workers, as their situation fits typical situations of precarious employment.

From a tourism research perspective, this study may seem a casual occurrence of volunteer working tourists trading their time, and muscles, for the opportunity to satisfy personal pursuits of extreme natural experiences. However, from a precarious work perspective, limitations considered, there are concerning questions that arise from the use of unpaid, informal labor that could affect the volunteer working tourists themselves, workers in the tourism industry, and workers rights and safety in general. While the practice is not isolated to the husky farm where the discussed working tourists volunteered, it is pertinent that further research be done into the conditions at other service providers to gain broader insight into the practice.

\section{Acknowledgement}

Research for the article was funded by The Finnish Work Environment Fund (www.tsr.fi).

\section{References}

Baum, T. (2012) Migrant Workers in the International Hotel Industry, Geneva: International Labor Organization.

Baym, N. K. (2000) Tune in, Log on: Soaps, Fandom, and Online Community, Thousand Oaks, CA: SAGE. doi: http://dx.doi.org/10.4135/9781452204710.

Bhalla, A. and P. McCormick. (2009) Poverty Among Immigrant Children in Europe, London: Palgrave Macmillan. doi: http://dx.doi.org/10.1057/9780230233973.

Bird, R. C. (2016) Precarious Work: The Need for Flextime Employment Rights and Proposals for Reform, 37 Berkeley J. Emp. \& Lab. L. doi: 10.2139/ssrn.2537997

Brennan, C. (2014a) Precarious Working Tourists: Working Holiday Makers in Australia, Tampere: Tampere University Press.

Brennan, C. (2014b) Backpackers or working holiday makers? Working tourists in Australia, Qualitative Sociology Review 10(3): 94-114.

Brennan, C. (2014c) Reexamining a 'working holiday': An autoethnography, Tourism 62(3): 277-292.

Broad, S. (2003) Living the Thai life-A case study of volunteer tourism at the Gibbon Rehabilitation Project, Thailand, Tourism Recreational Research 28(3): 63-72. doi: http://dx.doi.org/10.1080/02508281.2003.11081418. 
Brown, S. and X. Lehto. (2005) Travelling with a purpose: understanding the motives and benefits of volunteer vacationers, Current Issues in Tourism 8(6): 479-496. doi: http:// dx.doi.org/10.1080/13683500508668232.

Brown, S. and A. Morrison. (2003) Expanding volunteer vacation participation: an explanatory study on the minimission concept, Tourism Recreation Research 28(3): 73-82. doi: http://dx.doi.org/10.1080/02508281.2003.11081419.

Campbell, L. and S. Christy. (2006) What makes them pay? Values of volunteer tourists working for sea turtle conservation, Environmental Management August 2006. doi: http://dx.doi.org/10.1007/s00267-005-0188-0.

Campbell, I., G. Whitehouse and J. Baxter. (2009) Australia: Casual Employment, Part-time Employment and the Resilience of the Male-Breadwinner Model, Working Paper.

Clifton, J. and A. Benson. (2006) Planning for sustainable ecotourism: the case for research ecotourism in developing country destinations, Journal of Sustainable Tourism 14(3): 238-254. doi: http://dx.doi.org/10.1080/09669580608669057.

Correll, S. (1995) The ethnography of an electronic bar: the Lesbian cafe, Journal of Contemporary Ethnography 24(3): 270-298. doi: http://dx.doi.org/10.1177/089124195024003002.

Dow, C., M. Pittard, S. Sempill, J. Howe and M. Cullen. (2009) National Report: Australia, Theme 1 Regulatory Frameworks and Law Enforcement in New Forms of Employment, Report for XIX World Congress of Labor and Security Law, Sydney, September 2009.

Duncan, T. (2007) Working Tourists: Identity Formation in a Leisure Space, Doctoral dissertation. London: University of College London.

Enontekio Travel Blog on TravBuddy (2010) My Time at a Husky Farm, http://www.travbuddy.com/travel-blogs/75147/ [Accessed December 2015].

Flyn, C. (2013) My Winter on a Husky Farm in the Arctic Circle, The Telegraph. Published December 20 2013, http://www.telegraph.co.uk/travel/safaris-and-wildlife/My-winteron-a-husky-farm-in-the-Arctic-Circle/ [Accessed December 2015].

Fudge, J. and R. Owens. (2006) Precarious Work, Women and the New Economy: The Challenge to Legal Norms. In Fudge, J. and R. Owens. Precarious Work, Women and the New Economy: The Challenge to Legal Norms, Onati International Series in Law and Society. Oxford: Hart. doi: http://dx.doi.org/10.5040/9781472563651.ch-001.

Gunderson, A. (2005) More vacationers answer the call to help, The New York Times. February 20. http://travel.nytimes.com/2005/02/20/travel/20volunteer.html [Accessed January 2017].

Guttentag, D. (2009) The possible negative impacts of volunteer tourism, International Journal of Tourism Research 11: 537-551. doi: http://dx.doi.org/10.1002/jtr.727.

Handy, F. and J. Brundy. (2007) When to use Volunteer Labor Resources? An Organizational Analysis for Nonprofit Management, http://repository.upenn.edu/spp papers/91 [Accessed January 2017].

Hakkarainen, M. and S. Tuulentie. (2008) Tourism role in rural development of Finnish Lapland: interpreting national and regional strategy documents, Fennia 186(1): 3-13.

Hammersley, M. and Atkinson, P. (1995) Ethnography: Principles in Practice, New York, NY: Routledge.

Harding, G. and E. Webster. (2002) The Working Holiday Maker Scheme and the Australian Labor Market, Melbourne: Melbourne Institute of Applied Economic and Social Research, University of Melbourne.

Hetta, H. (2014) Volunteering at Hetta Huskies as a Trainee Arctic Safari Guide and Dog Handler, http://hettahuskies.com/activities/husky-guide-school/GuideManual.pdf [Accessed December 2015].

Hinterseer, T. (2013) Part-time work: Atypical? Precarious? Normal?, European Journal of Futures Research 1:18. 
Ho, C.-I., L. Pi-Yeah and H. Shu-Chin. (2012) Exploring Taiwanese working holiday-makers' motivations: an analysis of means-end hierarchies, Journal of Hospitality \& Tourism Research 38(4): 463-486. doi: http://dx.doi.org/10.1177/1096348012461549.

Jæger, K. and K. Olsen. (2016) On commodification: volunteer experiences in festivals, Journal of Tourism and Cultural Change: April 2016, 1-15. doi: http://dx.doi.org/10.1080/1 4766825.2016.1168827.

Jarvis, J. and V. Peel. (2009) 'Long Term Tourists or Short Term Migrants': The Impact of International Working Holiday Makers (WHMs) on the Tourism Economy of Mildura in Regional Victoria, Research Summary.

Jarvis, J. and V. Peel. (2010) 'Long Term Tourists or Short Term Migrants': The Impact of International Working Holiday Makers (WHMs) on the Tourism Economy of Mildura in Regional Victoria 2009-2010, Phase Two Results.

Kallenberg, A. (2009) Precarious work, insecure workers: employment relations in transition, American Sociological Review 74:1. doi: http://dx.doi.org/10.1177/000312240907400101.

Kawashima, K. (2010) Japanese working holiday makers in Australia and their relationship to the Japanese labor market: before and after, Asian Studies Review 34(3): 267-286. doi: http://dx.doi.org/10.1080/10357823.2010.508765.

Kay, J. and S. Laberge. (2002) Mapping the field go 'AR': adventure racing and Bourdieu's concept of field, Sociology of Sport Journal 19: 25-46. doi: http://dx.doi.org/10.1123/ ssi.19.1.25.

King, N. and C. Horrocks. (2010) Interviews in Qualitative Research, London: Sage.

Kozinets, R. V. (2002) The field behind the screen: using netnography for marketing research in online communities, Journal of Marketing Research 39: 61-72. doi: http://dx.doi. org/10.1509/jmkr.39.1.61.18935.

Kravaritou-Manitakis, Y. (1988) New Forms of Work: Labor Law and Social Security Aspects in the European Community, Luxembourg: European Foundation for the Improvement of Living and Working Conditions.

Kretsos, L. (2010) The persistent pandemic of precariousness: young people at work, in J. Tremmel (ed.), A Young Generation Under Pressure?, New York: Springer. doi: http:// dx.doi.org/10.1007/978-3-642-03483-1 1.

Kulavuz-Onal, D. and C. Vasquez. (2013) Reconceptualising fieldwork in a netnography of an online community of English language teachers, Ethnography and Education 8(2): 224-238. doi: http://dx.doi.org/10.1080/17457823.2013.792511.

Langer, R. and B. Suzanne. (2005) Sensitive research topics: netnography revisited, Qualitative Market Research 8:2. doi: http://dx.doi.org/10.1108/13522750510592454.

Lee, D., M. Hampton and J. Jeyacheya. (2015) The political economy of precarious work in the tourism industry in small island developing states, Review of International Political Economy 22(1): 194-223. doi: http://dx.doi.org/10.1080/09692290.2014.887590.

Lonan Jenkins Blog. (2013) https://lonanjenkins.wordpress.com/2014/03/20/home/ [Accessed December 2015].

Mayhew, C. and M. Quinlan. (2001) The effects of changing patterns of employment on reporting occupational injuries and making worker' compensation claims, Safety Science Monitor 5(1).

McGehee, N. and C. Santos. (2005). Social change, discourse, and volunteer tourism, Annals of Tourism Research 32(3): 760-779. doi: http://dx.doi.org/10.1016/j.annals.2004.12.002.

McGehee, N. G. and K. Andereck. (2008) Pettin' the critters': exploring the complex relationship between volunteers and the voluntoured in McDowell County, WV, USA and Tijuana, Mexico. In S. Wearing \& K. Lyons (Eds.), Journeys of Discovery in Volunteer Tourism: International Case Study Perspectives, Oxfordshire, UK: CABI. doi: http://dx. doi.org/10.1079/9781845933807.0012. 
McKay, S., S. Jefferys, A. Paraksevopoulu and J. Keles. (2012) Study on Precarious Work and Social Rights, London: European Commission

Mostafanezhad, M. (2014) Volunteer Tourism: Popular Humanitarianism in Neoliberal Times, Surrey: Ashgate Publishing Limited.

Mustonen, P. (2007) Volunteer tourism: altruism or mere tourism?, Anatolia: An International Journal of Tourism and Hospitality Research 18(1): 97-115. doi: http://dx.doi.org/10.10 $\underline{\text { 80/13032917.2007.9687038. }}$.

PAM. (2014) Collective Agreement for the Hotel, Restaurant and Leisure Industry, 1 May 2014 - 31 January 2017.

Porthé, V., F.G. Benavides, M.L. Vázquez, C. Ruiz-Frutos, A.M. García, E. Ahonen, A.A. Agudelo-Suárez and J. Benach. (2009) Precarious employment in undocumented immigrants in Spain and its relationship with health, Gac Sanit 23(Suppl 1): 107-114.

Rageh, A., T.C. Melewar, and A. Woodside. (2013) Using netnography research method to reveal the underlying dimensions of the customer/tourist experience, Qualitative Market Research: An International Journal 16(2): 126-149. Doi: http://dx.doi. org/10.1108/13522751311317558.

Rantala, O. (2010) Tourist practices in the forest, Annals of Tourism Research 37(1): 249-264. doi: http://dx.doi.org/10.1016/j.annals.2009.09.003.

Rantala, O. and J. Valkonen. (2011) The complexity of safety in wilderness guiding in Finnish Lapland, Current Issues in Tourism 14(6): 581-593. doi: http://dx.doi.org/10.1080/1368 3500.2010 .548548 .

Rantala, O., A. Valtonen, and V. Markuksela. (2011) Materializing tourist weather: ethnography on weather-wise wilderness guiding practices, Journal of Material Culture 16(3): 285-300 . doi: http://dx.doi.org/10.1177/1359183511413646.

Raudaskoski, H. (2010) Challenging Customer Service Situations in Small Tourism Businesses in Northern Finland, Masters Thesis: Haaga-Helia ammattikorkeakoulu

Sargeant, M. and A. Frazer. (2009) Older Workers as Vulnerable Workers in the New World Of Work, 15th World Congress of the International Industrial Relations Association (IIRA) (p. Workshop Sessions, Track 5: Session 3). Sydney: IIRA.

Standing, G. (2010) The Precariat: the New Dangerous Class, London: Bloomsbury.

Tan, Y., S. Richardson, L. Lester, T. Bai and L. Sun. (2009) Evaluation of Australia's Working Holiday Maker (WHM) Program, Canberra: Department of Immigration and Citizenship.

TE-palvelut. (2014) Santas Helper, http://www.mol.fi [Accessed September 2014]

TE-palvelut. (2014) Wilderness Guide, http://www.mol.fi [Accessed September 2014]

TE-palvelut. (2015) Driver, Tour Guide, http://www.mol.fi [Accessed December 2015]

TE-palvelut. (2015) Eraopas, http://www.mol.fi [Accessed November 2015]

TE-palvelut. (2015) Tarjoilija/Waitress, http://www.mol.fi [Accessed December 2015]

TE-palvelut. (2015) Vastaanottovirkailija/Receptionist, http://www.mol.fi [Accessed December 2016]

TE-palvelut. (2016) Toimistotyontekija, http://www.mol.fi [Accessed September 2016]

TE-palvelut. (2016) Tour Guide, Safari Guide, Kemi, http://www.mol.fi [Accessed November 2016]

TE-palvelut. (2016) Tour Guide, Safari Guide, Rovaniemi, http://www.mol.fi [Accessed November 2016]

TE-palvelut. (2016) Opas, http://www.mol.fi [Accessed June 2016]

TE-palvelut. (2016) Eraopas, http://www.mol.fi [Accessed November 2016]

TE-palvelut. (2016) Ravintolan tarjoilija, http://www.mol.fi [Accessed November 2016]

Time that is given (2013) Life on a Husky Farm, http://www.timethatisgiven.com/2013/10/ life-on-husky-farm.html [Accessed December 2015] 
Uriely, N. and A. Reichel. (2000) Working tourists and their attitudes to hosts, Annals of Tourism Research 27(2). doi: http://dx.doi.org/10.1016/s0160-7383(99)00071-7.

Uriely, N. (2001) Travelling workers' and 'working tourists': variations across the interaction between work and tourism, International Journal of Tourism Research 2. doi: http://dx. doi.org/10.1002/1522-1970(200101/02)3:1<1::aid-jtr241>3.3.co;2-d.

Uriely, N., A. Reichel, and A. Ron. (2003) Volunteering in tourism: additional thinking, Tourism Recreation Research 28(3): 57-62. doi: http://dx.doi.org/10.1080/02508281.2003.1 1081417.

Valkonena, J., H. Huilajaa and S. Koikkalainena. (2013) Looking for the right kind of person: recruitment in nature tourism guiding, Scandinavian Journal of Hospitality and Tourism, 13(3): 228-241. doi: http://dx.doi.org/10.1080/15022250.2013.837602.

Veijola , S. (2009) Gender as work in the tourism industry, Tourist Studies 9(2): 109-126. doi: http://dx.doi.org/10.1177/1468797609360601.

Wearing, S. (2001) Volunteer Tourism: Experience the Make a Difference, Oxford: CABI Publishing. doi: http://dx.doi.org/10.1079/9780851995335.0123.

Wearing S. (2002) Re-centering the self in volunteer tourism. In The Tourist as a Metaphor of the Social World, Dann G (ed.). CABI Publishing: New York: 237-262. doi: http://dx.doi. org/10.1079/9780851996066.0237.

Wearing S., A. Deville and K. Lyons. (2008) The volunteer's journey through leisure into the self. In Journeys of Discovery in Volunteer Tourism, Lyon K, Wearing S (eds). CABI Publishing: Cambridge, MA: 63-71. doi: http://dx.doi.org/10.1079/9781845933807.0063.

Wilson, K. (2004) Report for Exploratory Case Study Research into Precarious Employment, Wellington: Centre for Research on Work, Education, and Research Limited. New Zealand

Wilson, J., D. Fisher and K. Moore. (2009) “The OE goes 'home': Cultural aspects of a working holiday experience”, Tourist Studies 9: 3. doi: http://dx.doi.org/10.1177/1468797609360590.

Workaway.info. (2016) http://www.workaway.info [Accessed December 2017]

Workaway.info. (2016) Help at a hostel in Lapland, see the Northern Lights, http://www. workaway.info/376637641915-en.html [Accessed January 2016]

Workaway.info. (2016) Help at a husky and horse farm in arctic Lapland in the North of Finland, http://www.workaway.info/179431324188-en.html [Accessed January 2016]

Workaway.info. (2016) Help in our snow holiday resort in Lapland, Finland, http://www. workaway.info/979932641245-en.html [Accessed January 2016]

Workaway.info. (2016) Help needed from June-September,2015 located on north Lapland of Finland, http://www.workaway.info/223275191134-en.html [Accessed January 2016]

Workaway.info. (2016) Help out sami reindeerhearding family with tourists, located in Inari finnish lapland, http://www.workaway.info/378422565579-en.html [Accessed January 2016]

Workaway.info. (2016) Help with Siberian huskies and more in Finnish Lapland, http:// www.workaway.info/15879269594d-en.html [Accessed January 2016]

Workaway.info. (2016) Husky Experience - help on our husky farm with amazing dogs and care for guests in our lodge, Pallas-Yllästunturi National Park, Finland, http://www. workaway.info/846665835266-en.html [Accessed January 2016]

Workaway.info. (2016) Looking for Helper on a Huskyfarm in Levi, Finland, http://www. workaway.info/927764912694-en.html [Accessed January 2016]

Workaway.info. (2016) Volunteer in Finnish Lapland with huskies, http://www.workaway. info/714374818121-en.html [Accessed January 2016] 
Workaway.info. (2016) Want to volunteer in the snow on husky trails in Finland? http:// www.workaway.info/369989964293-en.html [Accessed January 2016]

YLE. (2016) 'More Asians fly to Lapland via Helsinki'. YLE News website, http://yle.fi/uutiset/more asians fly to lapland via helsinki/8606217 [Accessed December 2015]

\section{Notes}

1 The legality or illegality of such practice would have to be verified through further investigation. Regardless, the question about such can be raised from this initial observance.

2 The adverts were in English and thus directed to both prospective international and Finnish workers.

3 Ten listings were identified as being distinctly operating in the tourism sector in Lapland.

4 These are all work exchange websites for travelers and volunteers.

5 PDF 'Volunteering at...as a Trainee Arctic Safari Guide and Dog Handler' for Winter 2014.

6 The name of this company can be identified through references yet is not mentioned specifically within the text as it is not a case study.

7 See Enontekio Travel Blog on TravBuddy (2010) My time at a Husky Farm.

8 Twelve adverts were reviewed, for jobs such as Wilderness Guide and Tour Guide, and for tourism resorts.

9 This is a job search website organized by the Finnish government.

10 See Enontekio Travel Blog on TravBuddy (2010) My time at a Husky Farm.

11 PDF 'Volunteering at... as a Trainee Arctic Safari Guide and Dog Handler' for Winter 2014.

12 It is not known why the staff of the other husky safari companies quit nor if any were volunteer working tourists as well. 